\title{
ASSESSMENT OF EMERGENT AND FLOATING MACROPHYTES IN RELATION TO SOME PHYSICOCHEMICAL PARAMETERS OF WAYA POND, BAUCHI, NIGERIA
}

\author{
${ }^{* 1}$ Akwuma, O. D., ${ }^{2}$ Ezra, A.G. \& ${ }^{3}$ Nayaya, A.J.
}

\author{
${ }^{*} 123$ Department of Biological Sciences, Abubakar Tafawa Balewa University (ATBU) Bauchi, Bauchi State, Nigeria \\ *Corresponding Author's E-mail: edudanak@gmail.com Phone: +2347036705232
}

\begin{abstract}
Emergent and floating macrophytes in relation to some physicochemical parameters were assessed in Waya pond, Bauchi. Water and macrophytes were sampled monthly between October 2019 to March 2020. Ten physicochemical parameters were measured and twelve macrophytes species recorded. The diversity index was 1.38 , evenness $(0.55)$ and abundance were 12 species. The site was polluted as all the values of dissolved oxygen (DO) were $<5 \mathrm{mg} / \mathrm{L}$, nitrogen $>18 \mathrm{mg} / \mathrm{L}$ and $\mathrm{pH}<7$ except for December. Pearson's correlation coefficient revealed that DO correlated with Total Dissolved Solids (TDS) $(r=0.936, p<0.01)$, Phosphate $(r=0.927, p<0.01)$ and Nitrate $(r=-0.953$, $\mathrm{p}<0.01)$. TDS correlated with Phosphate $(\mathrm{r}=0.969, \mathrm{p}<0.01)$ and Nitrate $(\mathrm{r}=-0.938, \mathrm{p}<0.01)$. The significant correlation between physicochemical parameters and macrophytes were: Nymphaea nouchali with DO $(\mathrm{r}=-0.849, \mathrm{p}<0.05)$, TS $(\mathrm{r}=0.88, \mathrm{p}<0.05)$. Panicum repens was negatively correlated with TDS, DO, TS, Phosphate but not Nitrates. Eichhornia crassipes, Nymphaea micrantha and Nymphaea lotus at $\mathrm{p}<0.05$ were negatively associated with TDS, DO, and Phosphate but positively with Nitrate. Nuphar lutea, Nelumbo nucifera and Echinochloa colona related positively with Turbidity. Nuphar lutea positively related with Nitrate but negative with DO, and TS. Typha latifolia with TS $(\mathrm{r}=-0.871, \mathrm{p}<0.05)$. Potamogeton natans with phosphate $(\mathrm{r}=0.927, \mathrm{p}<0.01)$. The state of water pollution in the studyarea corresponded with low diversity, evenness and abundance of species. This puts biodiversity and sustainability at risk.
\end{abstract}

Keywords: biodiversity, correlation, macrophytes, parameters, physicochemical, pond.

LICENSE: This work by Open Journals Nigeria is licensed and published under the Creative Commons Attribution License 4.0 International License, which permits unrestricted use, distribution, and reproduction in any medium, provided this article is duly cited.

COPYRIGHT: The Author(s) completely retain the copyright of this published article.

OPEN ACCESS: The Author(s) approves that this article remains permanently online in the open access (OA) model.

QA: This Article is published in line with "COPE (Committee on Publication Ethics) and PIE (Publication Integrity \& Ethics)". 


\section{INTRODUCTION}

All living things cannot survive without water, especially aquatic organisms. It is therefore essential that water of suitable quality be made available for aquatic flora and fauna in a bid to ensure sustainability of resources for human use. Macrophytes are parts of aquatic flora and are valuable for the maintenance of ecological balance. Some macrophytes are edible, medicinal and feed for livestock. Water quality check is therefore key to knowing the right management policy that is required for biodiversity conservation, ecological sustainability and restoration but not further degradation. Biodiversity is typically a measure of variation. Rapid environmental changes typically cause mass extinctions (Cockell, et al., 2006; Bond and Wignall, 2008).

Aquatic macrophytes are a group of large macroscopic photosynthetic organisms usually growing with their roots in soil or water (Jones et al., 2012). Macrophytes are an important component of the aquatic ecosystem because they enhance the physical structure of habitats and biological complexity with increased biodiversity within the littoral zones (Wetzel, 2001). The depth, density, diversity and types of macrophytes present in a system are indicators of water body health (EPA, 2016). Researchers from the British Freshwater Habitats Trust defined pond as 'a man-made or natural water body that is between $1 \mathrm{~m}^{2}$ and $20,000 \mathrm{~m}^{2}$ in area, which holds water for four months of the year or more.' Other European biologists have set the upper size limit at 50,000 $\mathrm{m}^{2}$ (Céréghino, et al., 2008). According to Mukherjee and Palit (2012), Studies on the relationship between macrophytes and environmental factors in lentic ecosystems are rare. To close the existing research gaps, the aim of this study is to assess the diversity of emergent and floating macrophytes in relation to physicochemical parameters in Waya pond, Bauchi, North-East Nigeria.

\section{MATERIALS AND METHODS}

\section{STUDY AREA}

Ganjuwa is a local Government in Bauchi state Nigeria. It has a tropical savanna climate, annual average precipitation of $1,095 \mathrm{~mm}$, mean daily temperature of $25.4^{\circ} \mathrm{C}$, mean daily sunshine hours of 8.1 and is located within the coordinates of $10^{0} 18^{\prime} 50.9724^{\prime \prime} \mathrm{N}$ and $9^{0} 50^{\prime} 46.6152^{\prime \prime} \mathrm{E}$.

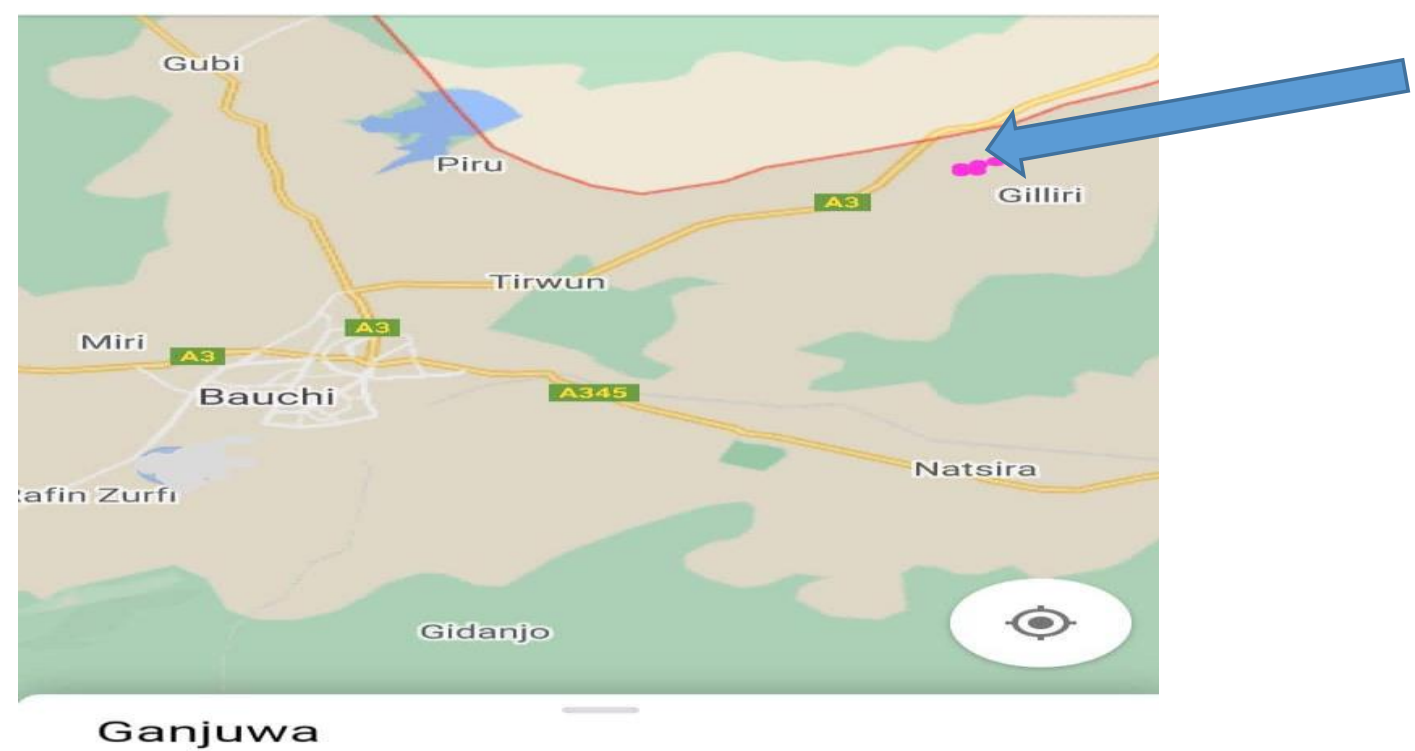

Figure 1: Map of Ganjuwa, Bauchi, showing the study area. Source: Google 


\section{SAMPLING STATION}

Waya pond is located at Gwari Yuli opposite Waya Dam at km 14 Maidugiri Road is about 156m long, 90m wide and $83 \mathrm{~m}$ away from the tar-road North wise, $2 \mathrm{~m}$ away from a newly yet to be tarred road at the western part while the Eastern and Southern parts were surrounded by maize farm land. Macrophytes and water samples were collected monthly between October 2019 to March 2020.

\section{COLLECTION OF WATER SAMPLES}

A 4-litre sample container was grasped near the base and the bottle opening plunged down-ward below the water surface with the opening pointed slightly upward, until it became filled with water. The container was then properly capped and transported in an ice chest to the laboratory for analysis (Delzer, 2003).

\section{ANALYSIS OF WATER SAMPLES}

Colorimeter hach DR 890 was used to determine turbidity. Determination of electrical conductivity (EC), $\mathrm{pH}$ and TDS were done in the laboratory using HANNA HI 9813-5. DO was measured by a JPB-70A pen type intelligent dissolved oxygen analyzer also in the laboratory. Determination of TS and TSS was by evaporation and filtration methods respectively. Phosphate and nitrate were determined by PALINTEST photometer Wagtech 7100 and the temperature was measured in situ using mercury thermometer

\section{MACROPHYTES COLLECTION AND ANALYSIS}

A quadrant of $1 \times 1 \mathrm{~m}^{2}$ (Goswami et al., 2014) was laid across each randomly selected point. All emergent and floating plants within the quadrant frame were identified using (Annelise et al., 2004) and recorded as described by (Nedungadi et al., 2013).

\section{STATISTICAL ANALYSIS}

Species composition, Shannon-Wiener diversity and evenness $H=\sum[(\mathrm{pi}) \times \ln (\mathrm{pi})]$ were calculated (Shannon, 1948). The relationship between physicochemical variables and with the macrophytes was analyzed with a Pearson correlation analysis at 95 and $99 \%$ level of confidence.

\section{RESULTS AND DISCUSSION}

Table I: Water Quality Parameters in Waya Pond, between October 2019 and March 2020.

\begin{tabular}{lcccccccccc}
\hline Months & \multicolumn{10}{c}{ parameters } \\
\hline & $\begin{array}{l}\text { DO } \\
(\mathrm{mg} / \mathrm{L})\end{array}$ & $\mathrm{pH}$ & $\begin{array}{l}\text { Temp } \\
\left({ }^{\circ} \mathrm{C}\right)\end{array}$ & $\begin{array}{l}\text { Turbid } \\
(\mathrm{Fau})\end{array}$ & $\begin{array}{c}\mathrm{EC} \\
(\mathrm{mS})\end{array}$ & $\begin{array}{c}\text { TDS } \\
(\mathrm{ppm})\end{array}$ & $\begin{array}{c}\text { TS } \\
(\mathrm{mg} / \mathrm{L})\end{array}$ & $\begin{array}{c}\text { TSS } \\
(\mathrm{mg} / \mathrm{L})\end{array}$ & $\begin{array}{c}\mathrm{PO}_{4} \\
(\mathrm{mg} / \mathrm{L})\end{array}$ & $\begin{array}{l}\text { Nit } \\
(\mathrm{mg} / \mathrm{L})\end{array}$ \\
\hline Oct. & 2.63 & 6.3 & 28.5 & 209 & 0.3 & 60 & 0.2 & 0.3 & 0.49 & 79 \\
Nov. & 2.97 & 6.9 & 27.1 & 30 & 0.7 & 76 & 0.1 & 0.6 & 0.24 & 61 \\
Dec. & 3.25 & 7.3 & 22.5 & 13 & 0.11 & 87 & 1.8 & 1.2 & 0.17 & 56 \\
Jan. & 3.98 & 6.8 & 11.8 & 18 & 0.32 & 233 & 1.1 & 0.6 & 3.00 & 46 \\
Feb. & 4.00 & 6.4 & 16.0 & 17 & 0.42 & 306 & 2.6 & 1.9 & 3.70 & 38 \\
March & 4.20 & 6.5 & 29.0 & 15 & 0.48 & 397 & 2.1 & 0.9 & 3.98 & 24 \\
\hline
\end{tabular}


Source: Akwuma et al. (2021). [Dissolved Oxygen (DO), Temperature (Temp) Electrical Conductivity (EC), Total Dissolved Solids (TDS), Total Solids (TS) Total Suspended Solids (TSS), Turbidity (Turbid), Phosphates $\left(\mathrm{PO}_{4}\right.$ ), Nitrate (Nit)]

Table II: Species Composition in Waya study area in Bauchi, October 2019 to March 2020.

\begin{tabular}{lccll}
\hline \multicolumn{1}{c}{ Species List } & $\begin{array}{c}\text { Number of } \\
\text { Samples }\end{array}$ & $\begin{array}{c}\text { Composition } \\
(\%)\end{array}$ & Family & Group \\
\hline Typha latifolia & 366 & 67.5 & Typhaceae & Emergent \\
Nymphaea lotus & 32 & 5.9 & Nymphaeaceae & Floating \\
Nymphaea micrantha & 25 & 4.6 & Nymphaeaceae & Floating \\
Panicum repens & 22 & 4.1 & Poaceae & Emergent \\
Nuphar lutea & 18 & 3.3 & Nymphaeaceae & Floating \\
Eichhornia crassipes & 16 & 3.0 & Pontederiaceae & Emergent \\
Peltandra virginica & 14 & 2.6 & Arum & Emergent \\
Scirpus atrovirens & 12 & 2.2 & Cyperaceae & Emergent \\
Nelumbo Nucifera & 11 & 2.0 & Nelumbonaceae & Floating \\
Echinochloa colona & 10 & 1.8 & Poaceae & Emergent \\
Nymphaea nouchali & 8 & 1.5 & Nymphaeaceae & Floating \\
Potamogeton natans & 8 & 1.5 & Potamogetonaceae & Floating \\
\hline
\end{tabular}

Total no. of individuals recorded 542

Table 1 shows the outcome of water quality parameters. Turbidity was lowest in December 2019 but highest in October 2019. This could be due to seasonal variation; October rainstorm, runoff and period of no-flow for the other months. Turbidity measurement may be affected by colored dissolved organic matter by causing low values as it absorbs light instead of scattering it. (Wetzel, 2001: Chen et al., 2007). The $\mathrm{pH}$ ranged from 6.3 to 7.3, indicating that the acidic tendency was higher than alkalinity tendency. The EC could be due to the surrounding geology. Also in diurnal variations as a body of water warms up due to sunlight, conductivity increases and then cools down at night (decreasing conductivity) (Wetzel, 2001). The low value of EC is attributed to the early morning sample collection.

The insufficient microbiological degradation of nutrients due to inadequate number of nitrogen-degrading microorganisms or the inability of the available ones could be the reason for the increase in nitrate concentration in October or the influx of organic materials into the water. Another reason for an increase in nitrate is its introduction into the pond via surface water runoff. This gained the support of (Puckett and Cowdery, 2002). Nitrate concentration exceeded $18 \mathrm{mg} / \mathrm{L}$ so the pond was in a polluted state during the study period. This gained the support of Mary et al, (2018) and Chapman, (1996) who stated that Nitrate concentrations in surface water is normally low (< $1 \mathrm{mg} / \mathrm{L})$ but can reach high levels as a result of agricultural runoff, refuse dump runoff or contamination with human or animal wastes. Phosphate concentration peaked in March due to the release of the previously absorbed phosphate into the 
water when the algae died but the lowest concentration in October could be due to the storage of phosphate by algae in their organism. This was supported by (Lizhi et al, 2018).

The concentration of DO was less than the recommended minimum of $6 \mathrm{mg} / \mathrm{L}$ (Akpofure, 2013). This is suggestive of pollution and threat to the aquatic Biota in the ponds. Low values of DO can be attributed to high deposit of organic matter from agricultural run-off into the water, decomposition of organic matter by micro-organisms, respiration by zooplankton, fish and other benthic organisms (APHA, 1990). The TDS values observed suggest that the macrophytes were very effective in reducing TDS. Though APHA (1999) stated that at most, fresh water can have 2000ppm of TDS and most sources should have much less than that. Hence, TDS values were within the acceptable range.

Table 2 shows the list, composition, family and group of individual plants. Diversity index $(\mathrm{H})$ was 1.38 , evenness $\left(E_{H}\right)$ was 0.55 and abundance was 12 species. It was found that notable, companionless, and supreme influence that explains the orderly or disorderly macrophytes' arrangement and composition in a community does not exist. Pearson's correlation coefficient revealed the significant association between physicochemical parameters: Dissolved Oxygen correlated with TDS, Phosphate and Nitrate in the following sequence; $(r=0.936, p<0.01),(r=$ $0.927, \mathrm{p}<0.01)$, and $(\mathrm{r}=-0.953, \mathrm{p}<0.01)$. TS positively correlated with TSS, TDS had strong positive correlation with Phosphate and Nitrate $(\mathrm{r}=0.969, \mathrm{p}<0.01),(\mathrm{r}=0.938, \mathrm{p}<0.01)$ while Phosphate and Nitrate were far apart $(\mathrm{r}=-0.861$, $\mathrm{p}<0.05)$.

The significant correlation between physicochemical parameters and Macrophytes species showed that: $N$. nouchali correlated with DO and TS negatively and positively respectively. Panicum repens had negative association with TDS, DO, TS but Nitrates all at $(\mathrm{p}<0.01)$ and with Phosphate negatively at $(\mathrm{p}<0.05) . N$. micrantha at $(\mathrm{p}<0.05)$ had a negative correlation with TDS, DO, TS and Phosphate but positive with Nitrate. N. lotus also associated negatively with TDS at $(\mathrm{p}<0.01), \mathrm{DO}$ and Phosphate at $(\mathrm{p}<0.05)$ but positively with Nitrate at $(\mathrm{p}<0.05)$. N. nucifera had positive correlation with Turbidity and Nitrate but negative with DO and TS at $(\mathrm{p}<0.05)$. Echinochloa colona strongly correlated with Turbidity positively $(\mathrm{r}=0.999, \mathrm{p}<0.01)$. T. latifolia with TS $(\mathrm{r}=-0.871, \mathrm{p}<0.05)$, Eichhornia crassipes negatively correlated with TDS at $(\mathrm{p}<0.01)$, phosphate, DO, but positively with nitrate at $(\mathrm{p}<0.05)$ for all. Potamogeton natans had strong positive correlation with phosphate $(\mathrm{r}=0.927, \mathrm{p}<0.01)$. Scirpus atrovireus was negatively correlated with; TDS, TS, DO at $(\mathrm{p}<0.01)$, but positively with phosphate at $(\mathrm{p}<0.05)$, and Nitrate at $(\mathrm{p}<0.01)$.

The significant negative correlation between dissolved oxygen and Macrophytes is attributable to overstimulation of algal growth by high levels of nutrients leading to depletion of DO or creation of anoxic condition, reduced transparency and changes in biotic community composition. This is confirmed by (Chislock et al. 2013). Anoxia can also result from a list of organic wastes. The positive significant correlations between macrophytes, turbidity and nitrates could be due to the decomposition of organic matter leads to the release of nitrate into the water column and their availability favours macrophytes community (APHA, 1990). Surface water runoff equally increases turbidity.

When macrophytes increased in frequency, the concentration of $\mathrm{PO}_{4}, \mathrm{EC}$, TS, TSS and TDS in the water column decreased. This suggests that the macrophytes improved the water quality by taking up toxicity, decreasing nutrients or dissolved organic matter and improving clearness of the water column. This was testified to by several 
studies (Scheffer, 1999; Cao et al., 2018). And in further support Tian et al. (2008) specified that a large amount of nutrients and suspended solids in the water column were absorbed for growth and reproduction.

\section{CONCLUSION}

In conclusion, the revealed state of this pond does not only correspond with a reduced macrophytes diversity and evenness but threatens faunal diversity also, hence biodiversity is at risk. This threat can be reduced if management strategies are employed to handle pollution.

\section{CONFLICT-OF-INTEREST}

There was no conflict of interest.

\section{ACKNOWLEDGMENTS}

The author wishes to acknowledge the contribution and support of: Daddy Adonai, Elder Akwuma Augustine Edoba, Anat. Akwuma Racheal and Mr. Jeremiah Michael, I.S. Bulai and H.I. Yakubu of Civil Engineering Laboratory ATBU, Shamwilu Saido Balloko Scientific Officer rural water supply \& sanitation agency (RUWASSA) Bauchi.

\section{REFERENCES}


Akpofure, R. (3013). Physico-Chemical and Biological Characteristics of Stagnant Surface Water Bodies (Ponds and Lakes) used for Drinking and Domestic Purposes in Niger Delta, Nigeria. Journal of Environmental Protection 4 (9) 920-928

APHA, American Public Health Association. American water works association \& water environment federation (1999). Standard Methods for the Examination of Water and Wastewater (20th edition).

APHA, American Public Health Association. American water works association \& water environment federation (1990). Standard Methods for the Examination of Water and Wastewater ( $15^{\text {th }}$ edition) Journal of American Public Health Association 160, 23-28.

Annalise G., Carina J.C., Carina V.G., and Rene G. (2004). Easy Identification of Aquatic Plants: a guide for the identification of water plants Department of Water Affairs and Forestry, South-African National Botanical Institute.

Bond, D. P.G. and Wignall, P. B. (2008). The Role of Sea-level change and Marine anoxia in the Frasnian-Famennian (Late Devonian) Mass Extinction. Palaeogeography, Palaeoclimatology, Palaeoecology. 263 (34): $107-118$.

Cao, X., Wan, L., Xiao, J., Chen, X., Zhou, Y., Wang, Z., et al. (2018). Environmental effects by introducing potamogeton crispus to recover a eutrophic lake. Science Total Environment 621, 360-367.

Céréghino, R.; Biggs, J.; Oertli, and B.; Declerck, S. (2008). "The ecology of European ponds: defining the characteristics of a neglected freshwater habitat". Hydrobiologia. 597 (1): 1-6.

Chen, Z., Hu, C., and Muller-Karger, F. (2007). Monitoring turbidity in Tampa Bay using MODIS/Aqua 250-m imagery., Remote Sensing of Environment. 109(2), 207-220.

Chislock, M. F., Doster, E., Zitomer, R. A. and Wilson, A. E. (2013). Eutrophication: Causes, consequences, and controls in aquatic ecosystems. Nature Education Knowledge 4 (4): 10.

Delzer, G.C., and Mckenzie, S. W. (2003). National Field Manual for the Collection of Water-Quality Data. (3 ${ }^{\text {rd }}$ edition) U.S. Geological Survey Techniques of Water Resources Investigations book 9.

Goswami, G., Pal, S., and Palit D. (2014). Studies on the physico-chemical characteristics, macrophyte diversity and economic prospect in Rajmata Dighi: a wetland in Cooch Behar Distict, West Bengal, India. NeBio $1(3), 21-27$.

Jones, J.I., Collins, A.L., Naden P.S., and Sear, D.A. (2012). The relationship between fine sediment and macrophytes in rivers. River research and Applications 28, 1006-1018.

Lizhi, W., Qianji, L., Changwei, H., Renjun, L., Jicai, Q., and Yun, W. (2018). Phosphorus release during decomposition of the submerged macrophyte Potamogeton crispus. Limnology 19, 355-366

Mary, H. W., Rena, R. J., Jean, D. B., Theo, M., Peter, J. W., Bernard, T. Nolan, Cristina, M. V. and Simeone, G. (2018). Drinking Water Nitrate and Human Health: an Updated Review. International Journal of Environmental Research and Public Health. 15(7):1557

Mukherjee, A. and Palit, D. (2012). Studies on Water Quality and Macrophyte Composition in Wetland of Bankura District, West Bengal, India. Indian Journal of Plant Sciences 1, 221-228. 
Nedungadi, P., Raman, R., and McGregor, M. (2013, October). Enhanced STEM learning with Online Labs: Empirical study comparing physical labs, tablets and desktops. In Frontiers in Education Conference 15851590.

Puckett, L. J. and Cowdery, T.K. (2002). Transport and fate of nitrate in glacial outwash aquifer in relation to groundwater age, land use practices. Journal of Environmental Quality 31 (3) 782-796

Scheffer, M. (1999). The Effect of aquatic vegetation on turbidity; how important are the filter feeders? Hydrobiologia 40, 307-316.

Shannon, C.E. (1948). The mathematical Theory of Communication. The Bell System Technical Journal, 27, 379-423 and $623-656$

Tian, L.V., Qiankun, H., Yaping, H., Chunhua, L., and Dan, Y. (2008). Effects of Water Quality Adjusted by Submerged Macrophytes on the Richness of the Epiphytic Algal Community. Front Plant Science, 2018; 9: 1980 